\title{
Kondisi Burnout pada Guru BK/Konselor di Sekolah Menengah Atas Negeri Kota Pekanbaru dan Implikasinya Bagi Peran Kepala Sekolah
}

\author{
Suci Habibah \\ Universitas Islam Negeri Sultan Syarif Kasim Rian \\ e-mail: suci.habibah@uin-suska.ac.id
}

\begin{abstract}
ABSTRAK. Penelitian ini dilatarbelakangi oleh masih terdapat Guru BK/Konselor yang mengalami kondisi kelelahan, stres dan kejenuhan dalam bekerja yang dikhawatirkan akan berujung pada kondisi burnout. Oleh karena itu, untuk mencegah dan mengatasi kondisi tersebut di perlukannya peran kepala sekolah sebagai pimpinan dari Guru BK/Konselor dan sebagai penanggung jawab kegiatan BK secara keseluruhan. Penelitian ini menggunakan metode kuantitatif jenis deskriptif. Populasi penelitian adalah Guru BK/Konselor SMAN se-Kota Pekanbaru. Sampel berjumlah 52 orang yang ditetapkan dengan teknik pengambilan sampel total Sampling. Instrumen yang digunakan adalah kuesioner burnout dengan model skala Likert. Temuan penelitian memperlihatkan bahwa 35,83\% Guru BK/Konselor mengalami kondisi burnout. Hal ini tentu menjadi perhatian karena akan mempengaruhi kinerja Guru BK. Oleh karena itu, dibahas lebih lanjut peran kepala sekolah untuk mengatasi dan mencegah kondisi burnout Guru BK/Konselor aga tidak semakin meningkat.
\end{abstract}

Kata kunci: Burnout, Guru BK/Konselor, Peran Kepala Sekolah.

\section{PENDAHULUAN}

Bimbingan dan Konseling (BK) merupakan bagian yang berperan penting dalam rangka mencapai tujuan pendidikan. Sebagai salah satu unsur pendidikan, layanan BK mempunyai peranan yang besar dalam membantu peserta didik untuk mengembangkan segala potensi yang dimilikinya untuk menghadapi kehidupan di masa yang akan datang. Kegiatan BK di sekolah, diselenggarakan oleh pejabat fungsional yang secara resmi dinamakan Guru BK/Konselor. Istilah Konselor muncul dalam Undang-undang Nomor 20 Tahun 2003 Pasal 1 Butir 6 menyebutkan bahwa "Konselor adalah pendidik. Konselor memiliki peran yang tak kalah penting dalam upaya membantu siswa untuk mencapai tugas-tugas perkembangannya, hal itu tentu memerlukan kemampuan personal dan profesional yang ada dalam diri Guru BK/Konselor. Peraturan Menteri Pendidikan dan kebudayaan Indonesia Nomor 111 tahun 2014 tentang Bimbingan dan Konseling Pasal 10 Ayat 2 menjelaskan bahwa tentang beban kerja yang harus dilaksanakan oleh Guru BK/Konselor yaitu: Guru BK/Konselor membimbing atau mengampu 150 orang siswa dan melakukan kewajiban lainnya sebagai Guru BK/Konselor, dan harus mampu melakukan tugas dan pekerjaannya secara optimal serta memiliki wawasan. selain itu, Guru BK/Konselor juga dituntut untuk mengembangkan potensi yang ada dalam diri siswa dan membantu siswa dalam mengatasi permasalahan yang dihadapinya baik dalam bidang pribadi, belajar, sosial, dan karir. Selain itu, Guru BK/Konselor juga diharapkan melakukan kolaborasi dengan orang tua, untuk mengembangkan potensi siswa. Hal ini sesuai dengan pendapat Afdal (2015) menjelaskan bahwa kegiatan kolaborasi dengan berbagai pihak (termasuk dengan orangtua) penting dilakukan 
oleh Guru BK/Konselor agar tercapainya tujuan pelayanan bimbingan dan konseling menuju perkembangan siswa yang mandiri dan optimal.

Berdasarkan penjelasan di atas terlihat banyaknya tugas dan tanggung jawab yang harus dilaksanakan oleh Guru BK/Konselor dalam mengembangkan potensi yang ada dalam diri peserta didik. Banyaknya tugas dan tuntutan yang harus dilaksanakan oleh Guru BK/Konselor tersebut lama kelamaan membuat Guru BK/Konselor akan cenderung mengalami kelelahan dan merasa jenuh terhadap aktivitas yang dilakukannya, kondisi kejenuhan ini sering juga dikatakan sebagai kondisi burnout. Hal ini di dukung oleh beberapa penelitian, diantaranya penelitian yang dilakukan oleh Sandra dan Ifdil (2015) menjelaskan bahwa Guru BK/Konselor ditugaskan untuk memandirikan siswa, mengembangkan potensi diri siswa, dan membantu siswa dalam mengentaskan masalah-masalah yang dialaminya baik di lingkungan sekolah maupun di lingkungan luar sekolah. Seorang Guru BK/Konselor diwajibkan membimbing 150 siswa, tetapi kenyataan di sekolah masih banyak Guru BK/Konselor yang membimbing siswa lebih dari beban kerjanya. Hal ini berdampak kepada kondisi Guru BK yang rentan mengalami stres dalam melakukan pekerjannya. Selanjutnya, Corey dan Corey (dalam Fernet, Guay, Caroline, dan Austin, 2012) menjelaskan bahwa Guru BK yang terlalu banyak bekerja dalam menghadapi klien akan mengalami kelelahan emosional yang akan mengarahkan dirinya pada kondisi kelelahan.

Sejalan dengan pendapat di atas, Kiarie, Sirera, dan Mwenje (2011) menjelaskan bahwa Guru BK memiliki resiko yang lebih tinggi terhadap kelelahan daripada individu dalam bidang pekerjaan lainnya. Selain itu, hasil penelitian Wozny, Polowczyk dan Zygmunt (2014) menunjukkan bahwa 54\% guru merasa stres dengan pekerjaan mereka. Selanjutnya, hasil penelitian Blazer (2010) mengenai teacher burnout diketahui bahwa kondisi burnout dalam profesi pengajaran telah diakui sebagai masalah serius. Penelitian ini menjelaskan bahwa kondisi burnout yang dialami oleh guru memiliki dampak negatif pada motivasi dan belajar siswa. Diperkirakan bahwa antara 5\% hingga 30\% guru menunjukkan gejala yang berbeda dari burnout pada waktu tertentu.

Berdasarkan wawancara dengan beberapa Guru BK/Konselor dari beberapa SMA di Pekanbaru pada tanggal 6 \& 7 Februari 2017 ditemukan bahwa, terdapat Guru BK/Konselor sering merasa sakit kepala setelah pulang dari sekolah sehingga mengganggu nafsu makan, saat menghadapi siswa terkadang Guru BK/Konselor kurang mampu mengendalikan emosi seperti marah dan membentak dalam memberikan layanan konseling, tidak terlalu mempedulikan tanggapan negatif orang lain terhadap kinerja BK, bagi Guru BK/Konselor jumlah siswa tidak sebanding dengan jumlah Guru BK/Konselor yang ada, Guru BK merasa bosan mengurusi permasalahan siswa yang sama. Berdasarkan penjelasan di atas dapat disimpulkan bahwa Guru BK/Konselor mulai menunjukkan adanya gejala kondisi burnout dengan karakteristik merasa lelah, energi menurun, mengalami gangguan fisik seperti sakit kepala, susah makan, cenderung tidak peduli, menjaga jarak dengan pekerjaan, dan merasa sinis dengan orang lain.

Chernis (1980) menjelaskan burnout merupakan perubahan sikap dan perilaku dalam bentuk reaksi menarik diri secara psikologis dari pekerjaan, seperti menjaga jarak dengan klien maupun bersikap sinis dengan mereka, membolos, sering terlambat, dan keinginan pindah kerja yang kuat. Pines \& Aronson (1989) mengemukakan burnout merupakan kelelahan secara fisik, emosional dan mental yang disebabkan keterlibatan jangka panjang dalam situasi yang penuh dengan tuntutan emosional. Berdasarkan pendapat di atas, dapat disimpulkan bahwa burnout merupakan kondisi kelelahan secara fisik, emosional dan mental yang membuat seseorang berperilaku menarik diri secara psikologis dari pekerjaan sebagai respon terhadap stres yang berlebihan. Burnout juga diartikan sebagai kondisi tertekan dalam bekerja atau kehilangan semangat dalam melakukan pekerjaannya. Maslach dan Leiter (1997) mengemukakan bahwa burnout merupakan sindrom psikologis yang terdiri atas tiga dimensi. Adapun tiga dimensi burnout adalah sebagai berikut: (1) exhaustion (kelelahan) dapat menyebabkan seseorang merasakan hal-hal lain secara berlebihan, baik secara emosional dan fisik, (2) cynicism (sinisme) yaitu perasaan sinis akan membuat orang mengambil sikap yang dingin dan berjarak terhadap pekerjaan dan orang-orang disekitarnya, (3) 
ineffectiveness (ketidakefektifan) merupakan perasaan tidak efektif, merasa diri semakin tidak mampu dalam melakukan pekerjaan.

Burnout dipengaruhi oleh beberapa faktor. Maslach dan Leiter (1997) menjelaskan bahwa penyebab terjadinya burnout dapat dilihat dari enam bentuk ketidaksesuaian antara orang dengan pekerjaannya yaitu: kelebihan beban kerja, kurangnya kontrol sistem, imbalan yang tidak memadai, terganggunya sistem komunitas dalam pekerjaan, hilangnya keadilan, dan konflik nilai. Selanjutnya, Gold dan Roth (1993) mengemukakan faktor yang mempengaruhi burnout pada guru diantaranya; kurangnya dukungan sosial, faktor demografis, konsep diri, peran konflik (peran ambiguitas), dan isolasi. Berdasarkan penjelasan di atas terlihat bahwa Guru BK/Konselor mulai menunjukkan gejala kondisi burnout dan kepala sekolah sebagai pemimpin yang akan mempertanggung jawabkan pelayanan BK secara keseluruhan, memiliki peranan yang penting dalam mengatasi sekaligus mencegah kondisi burnout tersebut. Tujuan penelitian ini adalah untuk mengetahui gambaran kondisi burnout Guru BK di SMAN Pekanbaru serta implikasinya bagi peran kepala sekolah.

\section{METODE PENELITIAN}

Berkenaan dengan kondisi burnout Guru BK/Konselor. Penelitian ini menggunakan pendekatan kuantitatif dengan jenis deskriptif. sampel ditetapkan dengan teknik total sampling. Instrumen yang digunakan adalah skala model Likert. Instrumen penelitian ini telah lulus validasi dari beberapa ahli dan lulus uji reliabilitas di lapangan. Untuk mengetahui gambaran kondisi burnout maka data dianalisis dengan rumus persentase. Lebih lanjut, berkenaan dengan peran kepala sekolah dilakukan dengan kajian pustaka yang berkaitan dengan peran kepala sekolah dalam mengatasi dan mencegah kondisi burnout.

\section{HASIL DAN PEMBAHASAN}

Deskripsi tingkat kondisi burnout Guru BK berdasarkan indikator dapat dilihat pada Tabel berikut.

Tabel 1. Deskripsi Data Kondisi Burnout Berdasarkan Indikator

\begin{tabular}{|c|c|c|c|c|c|c|c|}
\hline \multirow{2}{*}{ Sub Variabel } & \multicolumn{7}{|c|}{ SKOR } \\
\hline & Indikator & Ideal & Max & Min & $\Sigma$ & Mean & $\%$ \\
\hline \multirow[t]{4}{*}{$\begin{array}{l}\text { Exhaustion } \\
\text { (Kelelahan) }\end{array}$} & $\begin{array}{l}\text { Merasa tidak dapat bersantai } \\
\text { dalam bekerja }\end{array}$ & 25 & 14 & 5 & 511 & 9,8 & 39,31 \\
\hline & $\begin{array}{l}\text { Merasa lelah secara fisik ketika } \\
\text { bekerja }\end{array}$ & 25 & 13 & 5 & 469 & 9,01 & 36,08 \\
\hline & $\begin{array}{l}\text { Merasa lelah secara emosional } \\
\text { pada pekerjaan }\end{array}$ & 25 & 13 & 5 & 418 & 8,03 & 32,15 \\
\hline & $\begin{array}{l}\text { Perasaan tidak berdaya dalam } \\
\text { bekerja }\end{array}$ & 25 & 14 & 5 & 442 & 8,5 & 34 \\
\hline \multirow[t]{5}{*}{ Cynicism (sinisme) } & $\begin{array}{l}\text { Bersikap dingin dan memberi } \\
\text { jarak terhadap pekerjaan dan } \\
\text { orang-orang di sekitarnya }\end{array}$ & 25 & 13 & 5 & 486 & 9,34 & 37,38 \\
\hline & $\begin{array}{l}\text { Bersikap tidak peduli pada } \\
\text { pekerjaan }\end{array}$ & 20 & 13 & 5 & 393 & 7,55 & 37,79 \\
\hline & $\begin{array}{l}\text { Merasa terperangkap dalam } \\
\text { pekerjaannya }\end{array}$ & 25 & 13 & 5 & 421 & 8,09 & 32,38 \\
\hline & Mudah marah saat bekerja & 25 & 15 & 6 & 475 & 9,13 & 36,54 \\
\hline & Merasa cepat tersinggung & 25 & 12 & 4 & 372 & 7,15 & 35,77 \\
\hline
\end{tabular}




\begin{tabular}{|c|c|c|c|c|c|c|c|}
\hline \multirow{2}{*}{ Sub Variabel } & \multicolumn{7}{|c|}{ SKOR } \\
\hline & Indikator & Ideal & $\operatorname{Max}$ & Min & $\Sigma$ & Mean & $\%$ \\
\hline \multirow{6}{*}{$\begin{array}{l}\text { Ineffectiveness } \\
\text { (ketidakefektifan) }\end{array}$} & Berpandangan negatif & & 14 & & & & \\
\hline & $\begin{array}{l}\text { terhadap orang lain dalam } \\
\text { pekerjaan }\end{array}$ & 25 & & 6 & 487 & 9,36 & 37,46 \\
\hline & $\begin{array}{l}\text { Merasa tidak mampu dalam } \\
\text { pekerjaan }\end{array}$ & 25 & 13 & 6 & 468 & 9 & 36 \\
\hline & $\begin{array}{l}\text { Menganggap remeh hal yang } \\
\text { ingin dicapai }\end{array}$ & 25 & 14 & 5 & 468 & 9 & 36 \\
\hline & Merasa tidak percaya diri & 20 & 11 & 4 & 365 & 11 & 35 \\
\hline & Keseluruhan & 310 & 146 & 82 & 5775 & 111,05 & 35,83 \\
\hline
\end{tabular}

Tabel di atas mendeskripsikan bahwa secara rata-rata kondisi burnout Guru BK berada pada persentase 35,83\%. Hal ini dapat dilihat dari hasil analisis data pada masing-masing indikator, antara lain: merasa tidak dapat bersantai dalam bekerja yaitu sebesar 39,31\%, merasa lelah secara fisik ketika bekerja berada berada pada 36,08\%, merasa lelah secara emosional pada pekerjaan berada pada 32,15\%, perasaan tidak berdaya dalam bekerja berada $34 \%$, bersikap dingin dan memberi jarak terhadap pekerjaan dan orang-orang di sekitarnya sebesar 37,38\%, bersikap tidak peduli pada pekerjaan sebesar $37,79 \%$, merasa terperangkap dalam pekerjaannya sebesar 32,38\%, mudah marah saat bekerja 36,54\%, merasa cepat tersinggung yaitu sebesar 35,77\%, berpandangan negatif terhadap orang lain dalam pekerjaan sebesar $37,46 \%$, merasa tidak mampu dalam pekerjaan sebesar 36\%, menganggap remeh hal yang ingin dicapai sebesar 36\%, merasa tidak percaya diri pada sebesar $35 \%$.

Hasil penelitian menunjukkan bahwa pada umumnya kondisi burnout Guru BK SMAN seKota Pekanbaru berada pada 35,83\% . Hal ini berarti bahwa masih terdapat Guru BK yang mengalami kondisi burnout. Hal ini sejalan dengan penilitian Shukla \& Triveldi (2008) yang menjelaskan bahwa sekitar 56-64\% dari sampel menunjukkan bahwa guru di India memiliki tingkat burnout yang rendah dan sisa dari mereka berada pada kategori burnout sedang dan juga kategori tinggi. Oleh karena itu, kondisi burnout pada Guru BK harus di atasi agar tidak semakin meningkat. Dalam mengurangi kondisi burnout bagi Guru BK di butuhkannya peran dari personil sekolah lainnya, dan yang paling penting adalah peran Kepala Sekolah sebagai pimpinan Guru BK. Kepala sekolah adalah penanggung jawab pendidikan di sekolah secara keseluruhan, termasuk dalam pelaksanaan BK di sekolah. Kepala sekolah memegang peranan strategis dalam mengembangkan layanan BK di sekolah. Sehubungan dengan peranan kepala sekolah menurut Mulyasa (2007:98) kepala sekolah mempunyai 7 fungsi utama, yaitu: 1) kepala sekolah sebagai educator (pendidik), 2) kepala sekolah sebagai manajer, 3) kepala sekolah sebagai administrator, 4) kepala sekolah sebagai supervisor, 5) kepala sekolah sebagai leader (pemimpin), 6) kepala sekolah sebagai inovator, dan 7) kepala sekolah sebagai motivator. Di sisi lain, Purwanto (2002:65) mengemukakan bahwa seorang kepala sekolah mempunyai sepuluh macam peranan, yaitu: sebagai pelaksana, perencana, seorang ahli, mengawasi hubungan antara anggota-anggota, mewakili kelompok, bertindak sebagai pemberi ganjaran, bertindak sebagai wasit, pemegang tanggung jawab, sebagai seorang pencipta, dan sebagai seorang ayah. Yusuf (2006:112) menjelaskan keberhasilan kepala sekolah dalam meningkatkan kinerja guru BK/Konselor sekolah terletak pada kemampuan, kecakapannya sebagai leadership serta dapat memanfaatkan situasi serta kondisi yang ada.

Melihat begitu pentingnya peranan Kepala Sekolah dalam meningkatkan mutu pelayanan BK di sekolah, maka kepala sekolah memiliki peran dalam mengatasi dan mencegah terjadinya kondisi burnout Guru BK. Seorang kepala sekolah pada hakekatnya adalah pemimpin yang menggerakkan, mempengaruhi, memberi motivasi, serta mengarahkan orang di dalam organisasi atau lembaga pendidikan untuk mencapai tujuan yang telah ditentukan sebelumnya. Dalam menjalankan tugas dan tanggung jawab sebagai guru BK/Konselor, Guru BK/Konselor tersebut 
mengharapkan sebuah dukungan dari kepala sekolah agar pelaksanaan layanan BK tersebut berjalan dengan baik dan terarah. Hal ini sejalan dengan pendapat Arikunto (2011:46) menyebutkan bahwa komponen atau faktor-faktor yang menentukan keberhasilan pelayanan bimbingan dan konseling terdiri dari guru BK atau Konselor, siswa, kepala sekolah, sarana prasarana, proses pengelolaan, dan hasil layanan bimbingan dan konseling. Senada dengan hasil penelitian Djatmiko (2006) ditemukan bahwa kepemimpinan kepala sekolah berpengaruh terhadap kinerja guru SMP Negeri Kota Semarang sebesar 58,4\% , hal ini mengartikan bahwa variabel kepemimpinan kepala sekolah berpengaruh terhadap kinerja guru.

Berdasarkan hal di atas, terlihat bahwa peran kepala sekolah akan berpengaruh terhadap kinerja Guru BK/Konselor, termasuk di dalamnya mengatasi kondisi burnout, karena faktor faktor yang menentukan keberhasilan pelayanan bimbingan dan konseling salah satunya adalah peran kepala sekolah. Prayitno dan Amti (2004:65) mengemukakan bahwa pencapaian tujuan BK di sekolah terletak pada kemampuan kepala sekolah dalam melaksanakan fungsi dan tugasnya. Fungsi dan tugas tersebut antara lain: 1) mengkoordinir segenap kegiatan yang diprogramkan di sekolah, sehingga pelayanan pengajaran, latihan, dan BK merupakan suatu kesatuan yang terpadu, harmonis, dan dinamis, 2) menyediakan prasarana, tenaga, dan berbagai kemudahan bagi terlaksananya pelayanan BK yang efektif dan efisien, 3) melakukan pengawasan dan pembinaan terhadap perencanaan dan pelaksanaan program, penilaian dan upaya tidak lanjut pelayanan BK, 4) mempertanggungjawabkan pelaksanaan pelayanan BK di sekolah kepada Dinas Pendidikan yang menjadi atasannya, 5) memfasilitasi guru $\mathrm{BK} /$ Konselor untuk dapat mengembangkan kemampuan profesionalnya, melalui berbagai kegiatan pengembangan profesi, dan 6) menyediakan fasilitas, kesempatan, dan dukungan dalam kegiatan kepengawasan yang dilakukan oleh pengawas sekolah bidang BK. Kepala Sekolah merupakan salah satu penentu keberhasilan dalam pelaksanaan layanan BK.

Adapun upaya yang bisa dilakukan dalam mengatasi kondisi burnout menurut Herr dan Cramer (1984) diantaranya adalah: 1) mengambil waktu cuti pada pekerjaan untuk memulihkan psikologis dan mengembalikan semangat untuk bekerja pada diri, tentunya hal ini harus mematuhi aturan yang telah ditetapkan, 2) untuk mengatasi kelelahan dalam bekerja dan mengatasi kondisi burnout, Guru BK dapat diberikan pelatihan untuk mengenali dan menangani situasi burnout yang sedang dialaminya, 3) memberikan kesempatan untuk meningkatkan pengembangan karir atau jabatan, 4) Guru BK dapat diberikan kesempatan untuk berpastisipasi dalam pembuatan kebijakan, 5) Guru BK dapat diberikan kemandirian dalam pengambilan keputusan berkenaan dengan kebijakan atas pekerjaannya, 6) Guru BK yang mengalami kondisi burnout memungkinkan untuk dikurangi beban kerjanya dan variasi dalam jenis klien yang dilayani, 7) memberikan penghargaan dan pengakuan terhadap prestasi dan kinerja yang telah dilakukan oleh Guru BK, 8) Guru BK dapat melakukan rotasi kerja dengan Guru BK lainnya, pembagian kerja yang jelas dan berbagi dalam pekerjaan, 9) Guru BK juga bisa diberikan konseling untuk membahas pengembangan pekerjaan dalam suatu organisasi, 10) Guru BK yang mengalami burnout dapat diberikan kembali program orientasi, agar Guru BK mengetahui tugas dan tanggung jawab sebagai Guru BK, 11) Guru BK dapat diberikan lokakarya mengenai manajemen stres dan dukungan kelompok khususnya dalam kegiatan kelompok kerja Guru BK seperti: MGBK, dan 12) Guru BK dapat diberikan bantuan berkenaan dengan perencanaan karir.

Berdasarkan penjelasan di atas terlihat bahwa kepala sekolah berperan penting untuk mengatasi kondisi burnout Guru BK, kepala sekolah diharapkan senantiasa meningkatkan perannya dalam penyelenggaraan pelayanan BK dan mengetahui tugas dan tanggung jawabnya sebagai kepala sekolah dalam pembinaan pelayanan BK agar Guru BK terhindar dari kondisi burnout. Adapun hal yang bisa dilakukan kepala sekolah dalam mengatasi kondisi burnout Guru BK. Untuk sub variabel exhaustion (kelelahan) kepala sekolah dapat memberikan waktu cuti pada Guru BK untuk memulihkan kondisi psikologis dan mengembalikan semangat untuk bekerja pada diri Guru $\mathrm{BK}$, tentunya hal ini harus mematuhi aturan yang telah ditetapkan. Selanjutnya, untuk mengatasi 
kelelahan dalam bekerja dan mengatasi kondisi burnout pada Guru BK, kepala sekolah diharapkan dapat membantu agar Guru BK diberikan pelatihan untuk mengenali dan menangani situasi burnout yang sedang dialaminya. Selanjutnya, kepala sekolah diharapkan bisa mengurangi beban kerja Guru BK dan memberikan variasi dalam jenis klien yang dilayani oleh Guru BK yang mengalami kondisi burnout.

Untuk mengatasi kondisi burnout Guru BK pada sub variabel cynicism (sinisme) kepala sekolah dapat memberikan kesempatan kepada Guru BK untuk meningkatkan pengembangan karir atau jabatan, kepala sekolah dapat memberikan kesempatan kepada Guru BK untuk berpastisipasi dalam pembuatan kebijakan, selanjutnya, kepala sekolah dapat memberikan kepercayaan kepada Guru BK agar mandiri dalam pengambilan keputusan berkenaan dengan kebijakan atas pekerjaannya sebagai Guru BK. kepala sekolah dapat memberikan kegiatan yang dapat menciptakan keakraban antar personil sekolah, seperti: gathering, outbound, rekreasi, dan sharing bersama anggota personil sekolah lainnya. Selanjutnya, peran yang bisa dilakukan oleh kepala sekolah dalam mengatasi kondsi burnout pada sub variabel ineffectivenes (ketidakefektifan), kepala sekolah hendaknya memberikan penghargaan dan pengakuan terhadap prestasi dan kinerja yang telah dilakukan oleh Guru BK, kepala sekolah juga bisa melakukan diskusi dengan Guru BK untuk membahas pengembangan pekerjaan dalam suatu organisasi. Selain itu, kepala sekolah dapat memberikan kembali program orientasi kepada Guru BK yang mengalami burnout, agar Guru BK mengetahui tugas dan tanggung jawab Guru BK, Guru BK dapat diberikan lokakarya mengenai manajemen stres dan dukungan kelompok khususnya dalam kegiatan kelompok kerja Guru BK seperti: MGBK, kepala sekolah dapat memberikan bantuan berkenaan dengan perencanaan karir bagi Guru BK.

Secara keseluruhan peran kepala sekolah untuk mengatasi kondisi burnout pada Guru BK dapat dilakukan dengan mengkoordinir program layangan BK dengan baik, menyediakan prasarana, tenaga, agar terlaksananya pelayanan BK yang efektif dan efisien, melakukan pengawasan dan pembinaan terhadap perencanaan dan pelaksanaan program, penilaian dan upaya tidak lanjut pelayanan BK, memfasilitasi guru BK/Konselor untuk dapat mengembangkan kemampuan profesionalnya, melalui berbagai kegiatan pengembangan profesi, menyediakan fasilitas, kesempatan, dan dukungan bagi Guru BK/Konselor sehingga Guru BK/Konselor dapat mencapai prestasi kerja dengan baik dan terhindar dari kondisi burnout.

\section{SIMPULAN}

Berdasarkan temuan dan pembahasan hasil penelitian, maka dapat dikemukakan kesimpulan sebagai berikut: Kondisi burnout Guru BK berada pada persentase 35, 83\%, hal ini perlu menjadi perhatian bagi Guru BK, dan pihak terkait didalamnya, agar kondisi burnout yang di alami oleh Guru BK tidak semakin tinggi dan dapat teratasi dengan baik. Hasil yang diperoleh dalam penelitian ini dapat dijadikan bahan masukan bagi Guru BK dalam rangka mengatasi kondisi burnout Guru BK dan masukan bagi kepala sekolah agar memiliki pemahaman yang utuh berkenaan dengan pelayanan BK di sekolah mengenai faktor yang mempengaruhi kondisi burnout. Selain itu, untuk mengatasi kondisi burnout Guru BK/Konselor di perlukannya kepala sekolah, kepala sekolah dapat mengkoordinasikan kegiatan bimbingan dan konseling di sekolah dengan baik, kepala sekolah memberikan dukungan sosial terhadap Guru BK/Konselor agar Guru BK merasa diperhatikan, merasa dihargai dalam melakukan tugas dan tanggung jawabnya sebagai Guru BK/Konselor, kepala sekolah diharapkan dapat mengkomunikasikan kerja BK kepada personil sekolah lainnya agar program BK di sekolah dapat berjalan dengan baik agar mendapatkan dukungan, serta kerja sama dari pihak yang terkait, selain itu, kepala sekolah diharapkan dapat meningkatkan sarana prasarana yang dibutuhkan oleh Guru BK/Konselor dalam melaksanakan layanan BK, sehingga dengan demikian pelaksanaan layanan BK berjalan dengan baik dan Guru BK dapat terhindar dari kondisi burnout. 


\section{REFERENSI}

Afdal, A. (2015). Kolaboratif: Kerangka kerja konselor masa depan. Jurnal Konseling dan Pendidikan, $3(2), 1-7$.

Arikunto, S. 2011. Dasar-dasar Evaluasi Pendidikan: Edisi revisi. Jakarta: Bumi Aksara.

Blazer, C. (2010). "Teacher Burnout". Information Capsule Research Services Office of Assesment, Research, and Data Analysis, 1003, 1-19.

Cherniss, C. (1980). Staff Burnout: Job stress in the human services. London: Dage Publications.

Djatmiko, E. (2006). Pengaruh kepemimpinan kepala sekolah dan sarana prasarana terhadap kinerja guru smp negeri kota semarang. Fokus Ekonomi, 1(2).

Fernet, C., Guay, F., dan Austin, S. (2012). Predicting Intraindividual Changes in Teacher Burnout: The role of perceived school environment and motivational factors. Journal Teaching and Teacher Education, 28, 514-525.

Gold,Y., dan Roth, R. A. (1993). Teachers Managing Stress and Preventing Burnout: The professional health solution. London: The Flamer Prees.

Herr, E. L., dan Cramer, S. H. (1984). Career Guidance and Counseling Through the Life Span. Boston: Little Brown Company.

Ihsan, A. J. N. (2005). Manajemen Bimbingan dan Konseling di SMP: Kurikulum 2004. Jakarta: Grasindo.

Kiarie, J. M., Sirera, A., dan Mwenje, M. (2011). The Effect of Burnout on Teacher Counselors Work Engagement. Kenyan Journal of Guidance, Counseling and Psychology, 1(1), 2437.

Maslach, C., dan Leiter, M, P. (1997). The Truth About Burnout. San Francisco: Jossey Bas.

Mulyasa, E. 2007. Menjadi Kepala Sekolah Profesional. Bandung: Remaja Rosdakarya.

Peraturan Mentri pendidikan dan Kebudayaan Indonesia Nomor 111 Tahun 2014. Tentang Bimbingan dan Konseling pada Pendidikan Dasar dan Menengah. Jakarta: Sekatariat.

Pines, A., dan Aronson, E. (1989). Career Burnout: Causes and cures. New York: The Free Press, A Division of Macmillan.

Prayitno. (1997). Pelayanan Bimbingan dan Konseling (SLTP). Jakarta: Bina Sumber Daya MIPA

Prayitno dan Amti, E. 2004. Pedoman Khusus Bimbingan dan Konseling. Jakarta: Depdiknas.

Purwanto, N. 2002. Administrasi dan Supervisi Pendidikan. Bandung: Remaja

Sandra, R., dan Ifdil, I. (2015). Konsep Stres Kerja Guru Bimbingan dan Konseling. Jurnal Educatio: Jurnal Pendidikan Indonesia, 1(1), 80-85.

Shukla, A., dan Triveldi, T. (2008). Burnout in Indian Teachers. Asia Pacific Education Review. University of Lucknow India, 9(3), 320-334.

Soetjipto., dan Kosasi, R. (2009). Profesi Keguruan. Jakarta: Asdi Mahasatya.

Undang-undang Nomor 20 Tahun 2003 tentang Sistem Pendidikan Nasional. Jakarta: Kementerian Pendidikan Nasional.

Wozny, K. W., Polowczyk, L. S., \& Zygmunt, A. (2014). "Stress in the Teaching Profession". Journal of Education, Health and Sport, 5(6), 191-210.

Yusuf, S. 2006. Program Bimbingan dan Konseling di Sekolah (SLTP dan SLTA). Bandung: Pustaka Bani Quraisy. 